\title{
Determinants of Main actors' Satisfaction with Issues Related to the Value chain of Organic Fruits, Vegetables and Spices in North Eastern Nigeria
}

\author{
O. Taofeeq Yekinni, T. Adejoju Ladigbolu, and O. James Ogundijo
}

\section{ABSTRACT}

Reflection on the current system of issues related to organic fruits, vegetables and spices is essential to find out the potential opportunities, barriers, and benefits along the chain. The study was conducted on determinants of main actors' satisfaction with issues related to organic fruits, vegetables, and spices in North-eastern Nigeria. Multi-stage sampling procedure was used to select 120 respondents. Data were collected on respondents' socioeconomic characteristics; needs and priorities; level of knowledge, benefits derived and satisfaction with issues related to the value chain. Differences in respondents' satisfaction across the states and determinants of their satisfaction with issues related to the value chain were tested. Data were analyzed using frequency counts, percentages, weighted score, analysis of variance and linear regression at $\alpha \mathbf{0 . 0 5}$.

Results showed $58.2 \%$ of the respondents were between 21-35 years, female $(59.2 \%)$ and had less than 5 hectares farm size $(57.5 \%)$. They produced organic cucumber $(0.76)$, okro $(0.72)$, onions $(0.74)$ and derived benefits from zero expense on inorganic pesticides $(\mathbf{9 5 . 0 \%})$. They were satisfied with organic land tenure system $(\mathbf{5 3 . 3 \%})$ and had high level of knowledge $(53.3 \%)$. Their needs and priorities were more fertile land (294.4) and increased market (283.3). A significant difference $(F=4.35 ; p=0.02)$ existed among respondents' satisfaction across the states. Level of knowledge $(\beta=0.19$; $p=0.04)$ and benefits derived $(\beta=0.30 ; p=0.00)$ determined their satisfaction with issues related to organic fruits, vegetables, and spices. Hence, frequent organic workshop and training are recommended to keep respondents updated about issues related about issues related to the value chain.

Keywords: Actors, Needs and priorities, Organic fruits, Satisfaction, Spices.
Submitted: June 09, 2021

Published: August 31, 2021

ISSN: $2684-1827$

DOI: 10.24018 /ejfood.2021.3.4.322

\section{O. T. Yekinni*}

Department of Agricultural Extension and rural development, Faculty of Agriculture, University of Ibadan, Ibadan, Oyo state Nigeria

(e-mail: taofeeqyekinni@ gmail.com)

T. A. Ladigbolu*

Department of Agricultural Extension and rural development, Faculty of Agriculture, University of Ibadan, Ibadan, Oyo state Nigeria.

(e-mail: adejojutemitope ${ }^{\circledR}$ gmail.com)

O. J. Ogundijo

Federal University of Agriculture, Abeokuta, Ogun state, Nigeria.

(e-mail: jamesogundijo@yahoo.com)

*Corresponding Authors

\section{INTRODUCTION}

Agriculture in Northern Nigeria dates as far back as the pre-colonial era, [1] and the region has since then been leading in the production and sales of various agricultural produce ranging from grains, spices, vegetables, livestock and to fruits. Major fruits produced in Northern Nigeria include mango, pineapple, plantain/banana, citrus, guava, pawpaw, while vegetables include onion, tomato, okra, pepper, amaranthus, carrot, melon, Corchorus olitorus (ewedu), Hibiscus sabdariffa (sobo), Adansonia digtata (baobab leaves), all which could be produced either conventionally or organically.

Meanwhile, organic agriculture is the practice of cultivation of crops and rearing livestock without applying synthetic chemicals, pesticides and inorganic fertilisers which aims at human ecology and environment welfare. It combines the application of innovation, traditional knowledge and science to benefit the shared environment and promote fair relationships as well as improve good quality of life for all involved, [2]. Emerging and increasing trend of organic agriculture in the world might have various consequences on different stakeholders involved in the value chain and the producers (farmers) take the most important place along the chain, [3] value chain is a full range of activities which are required to bring a product or service from conception, through the different phases of production (involving a combination of physical transformation and the input of various producer services), to delivery for consumption and finally disposal after use.

Importance of organic fruits vegetables and spices along the value chain cannot be overemphasised; it can create more working opportunities, help more small farmers to improve their livelihood status as well as improve consumers' health, [4]. These food crops have greatly contributed to the nutritional needs of the populace due to their affordability and availability to every stratum of the society. Previous researches have shown that organic agriculture can be an approach of poverty reduction for smallholder farmers [5][7].

Past studies have focused on organic agriculture, environment and food security, training needs and gender involvement in organic agriculture and farmers' perception of organic farming, [8]-[12]. Despite, the various studies on organic agriculture coupled with benefits embedded in the production and consumption of organic vegetables, spices and fruits, there is limited information on actors' satisfaction 
with issues related to the value chain of organic fruits, vegetables, and spices in Nigeria. Therefore, it is against this background that the study investigated factors that determine main actors' satisfaction with issues related to the value chain of organic fruits, vegetables, and spices in North-eastern Nigeria. The following specific objectives guided the study:

1.to describe the socioeconomic characteristics of the respondents;

2.to determine producers' (main actors) level of knowledge about principles and practices of organic agriculture;

3.to ascertain benefits derived by the respondents from participation in the value chain of organic fruits, vegetables and spices;

4.to establish respondents' satisfaction with issues related to (production, marketing, and processing) the value chain of organic fruits, vegetables and spices;

5.to identify the needs and priorities of respondents in the value chain of organic fruits, vegetables and spices.

Test of hypotheses

H01: Selected variables do not significantly determine respondents' satisfaction with issues related to (production, marketing, and processing) the value chain of organic fruits, vegetables, and spices.

H02: There is no significant difference in respondents' satisfaction with issues related to (production, marketing, and processing) the value chain of organic fruits, vegetables, and spices across the states.

\section{Methodology}

The study was carried out in North-Eastern region of Nigeria. Literature have shown that the region is located between latitude $905^{\prime} \mathrm{N}$ to $13044^{\prime} \mathrm{N}$ and longitude $9050^{\prime} \mathrm{E}$ to $14038^{\prime} \mathrm{E}$ [13], [14], with land resources of $176000 \mathrm{~km}^{2}$ (68 $000 \mathrm{mi}^{2}$ ). Northeast, Nigeria comprises six states (Adamawa, Borno, Bauchi, Yobe, Gombe and Taraba). The population of this study, main actors in the organic fruits, vegetables and spices value chain were selected using multistage sampling procedure. First off, $50.0 \%$ of states in the Northeast agro-ecological zone of Nigeria was selected using simple random sampling technique and this resulted in selection of three (Gombe, Adamawa and Taraba states) out of six states in the zone. In the second stage, $10.0 \%$ of 16 Local Government Areas (LGAs) in Taraba, 21 LGAs in Adamawa and $7.0 \%$ of 11 LGAs in Gombe states were selected using a simple random sampling technique. This amount to six local government areas in all. In the third stage, $20.0 \%$ of wards from 2 selected LGAs in Taraba and Adamawa states as well as and $15.0 \%$ of wards from 2 selected LGAs in Gombe state were also selected using a simple random technique, In all 12 wards were selected. The fourth stage involved selection of at least one village from the 12 selected wards which amount to 12 villages, the selection was done using simple random technique. Then in the villages 40 farming households were sampled using simple random technique. Therefore, one hundred and twenty main actors were sampled for this study. Data were collected using structured interview schedule. Data were analysed using percentage, mean and weighted score, analysis of variance and linear regression at $\alpha 0.05$.

Respondents' socioeconomic characteristics like age, sex, household size, farm size, years of farming experience, role played in the value chain, the kind of organic fruit, vegetable and spices they deal with among others were measured in nominal and interval level of measurement as the case dictated.

Level of respondent's satisfaction with issues related to (production, processing and marketing) the value chain of organic fruits, vegetables and spices was measured by providing respondents with 16 items. They were provided with five response options of "Very Satisfactory (VS)", "Satisfactory (S)", "Neutral (N)", "Unsatisfactory (U)" and "Very Unsatisfactory (VU)". Scores of 5, 4, 3, 2, and 1 were assigned to the response options respectively, the minimum obtainable score was 16 while the maximum obtainable score was 80 . Then, weighted mean score was computed for each score in order to rank the satisfaction item before satisfaction index was then computed. The Mean of satisfaction index scores was used to categorise the respondents into low and high level of satisfaction.

Respondents' level of knowledge of the respondents on organic agriculture practices and principles was measured based on the principles and practices of organic agriculture in Nigeria. Twenty knowledge items in form of objectives questions were provided for the respondents with at least two response options (maximum of three) including one correct answer. Eventually all correct answers were scored 1 and wrong answers scored 0 . The maximum obtainable score was 20 with minimum 0 . Knowledge index was then computed to determine the level of respondent knowledge about principles of organic agriculture. Using mean as the benchmark, knowledge index was categorised into high and low level of knowledge. Respondents with mean score and above were categorised as high while those with scores below mean were categorised as having low level of knowledge about organic agriculture practices and principles.

\section{RESULTS AND DISCUSSION}

\section{A. Socioeconomic Characteristics of the Respondents}

Table I shows that more than majority $(58.2 \%)$ of main actors were between age range 21-35 years. This implies that they are youth according to [15] agile and health to put up with the rigours of farming. More than half (59.2\%) were female, married $(64.2 \%)$, had secondry education $(31.7 \%)$ and majority $(63.3 \%)$ had at least $1-5$ persons in their households. Table I also presents that half (57.5\%) of them had less than 5 hectares farm size, $95.8 \%$ had 1-10 years farming experience and $57.5 \%$ were not organically certified. This could probably mean that either they practiced organic agriculture by default, or they are in the process of getting their activities certified.

Meanwhile, when asked why they were not registered or certified, majority $(80.4 \%)$ of them implicate lack of fund, while $74.5 \%$ of those that were certified indicate that they were certified under Participatory Guarantee System. This is understandable as organic certification is quite expensive for smallholder farmers to obtain. Table I also shows that roles 
played by the respondents were interwoven while majority $(84.2 \%)$ were producers, a higher percentage $(97.3 \%)$ were involved in marketing, only a few (12.5\%) involved in processing of their produces and many $(74.7 \%)$ of them consumed what they produced.

TABLE I: MAIN ACTORS' SOCIOECONOMIC CHARACTERISTICS

\begin{tabular}{|c|c|c|}
\hline Characteristics & Frequency & Percentage \\
\hline \multicolumn{3}{|l|}{ Age categories } \\
\hline 21-35 years & 71 & 59.2 \\
\hline 36-51years & 41 & 34.2 \\
\hline 51 years and above & 8 & 6.7 \\
\hline Total & 120 & 100 \\
\hline \multicolumn{3}{|l|}{ Sex } \\
\hline Female & 71 & 59.2 \\
\hline Male & 49 & 40.8 \\
\hline Total & 120 & 100 \\
\hline \multicolumn{3}{|l|}{ Marital status } \\
\hline Single & 34 & 28.3 \\
\hline Married & 77 & 64.2 \\
\hline Widowed & 13 & 7.5 \\
\hline Total & 120 & 100 \\
\hline \multicolumn{3}{|l|}{ Household size } \\
\hline $1-5$ persons & 76 & 63.3 \\
\hline $6-10$ persons & 41 & 34.2 \\
\hline 11 persons and above & 3 & 2.5 \\
\hline Total & 120 & 100 \\
\hline \multicolumn{3}{|l|}{ Educational background } \\
\hline No formal education & 15 & 12.5 \\
\hline Primary education & 36 & 30.0 \\
\hline Secondary education & 38 & 31.7 \\
\hline Tertiary education & 31 & 25.8 \\
\hline Total & 120 & 100 \\
\hline \multicolumn{3}{|c|}{ Are your organic activities certified? } \\
\hline No & 69 & 57.5 \\
\hline Yes & 51 & 42.5 \\
\hline Total & 120 & 100 \\
\hline \multicolumn{3}{|c|}{ Kind of certificate acquired $(n=51)$} \\
\hline Third party & 38 & 75.5 \\
\hline $\begin{array}{l}\text { Participatory } \\
\text { guarantee system }\end{array}$ & 13 & 25.5 \\
\hline Total & 51 & 100 \\
\hline \multicolumn{3}{|c|}{$\begin{array}{l}\text { Main actors' reasons for non-registered organic stakeholders } \\
(\mathrm{n}=51)\end{array}$} \\
\hline New in the business & 41 & 80.4 \\
\hline Lack of fund & 10 & 19.6 \\
\hline Total & 51 & 100 \\
\hline \multicolumn{3}{|l|}{ Farm size } \\
\hline Less than 5 hectares & 69 & 57.5 \\
\hline $5-14$ hectares & 49 & 40.8 \\
\hline 15 hectares and above & 2 & 1.7 \\
\hline Total & 120 & 100 \\
\hline \multicolumn{3}{|l|}{ Years of experience } \\
\hline $1-10$ years & 115 & 95.8 \\
\hline $11-20$ years & 5 & 4.2 \\
\hline Total & 120 & 100 \\
\hline \multicolumn{3}{|c|}{ Roles played in the value chain } \\
\hline Producers/producing & 89 & $84.2 * *$ \\
\hline Marketers/marketing & 11 & $97.3 * *$ \\
\hline Processors/processing & 15 & $12.5^{* *}$ \\
\hline Consumers/consuming & 5 & $74.7 * *$ \\
\hline
\end{tabular}

Source: Field survey 2020.

*** Multiple responses.

\section{B. Organic Fruit, Vegetables and Spices that Respondents deal with in the Value Chain}

Data in Table II presents that among organic fruits that main actors dealt with were cucumber $(0.76)$, banana $(0.53)$, watermelon (0.53) and plantain $(0.50)$ but among organic vegetables they dealt with okro (0.72), lettuce $(0.62)$, garden egg (0.58), cabbage (0.57) and ugu (0.55). Meanwhile, among spices, they dealt with organic onion (0.74), pepper (0.71), and ginger (0.66). This implies that main actors dealt with (either produced, marketed, processed, or consumed) organic cucumber, onion, okro, pepper, ginger, lettuce, garden egg, cabbage and ugu (pumpkin) as they were generally ranked $1^{\text {st }}$, to $10^{\text {th }}$ respectively among other fruits, vegetables and spices.

TABLE II: ORGANIC FRUIT, VEGETABLES AND SPICES THAT RESPONDENTS DEAL WITHIN THE VALUE CHAIN

\begin{tabular}{cccc}
\hline $\begin{array}{c}\text { Organic fruits, } \\
\text { vegetable, and spices }\end{array}$ & Mean score & $\begin{array}{c}\text { Rank within } \\
\text { group }\end{array}$ & $\begin{array}{c}\text { Overall } \\
\text { rank }\end{array}$ \\
\hline Fruits & & & \\
\hline Cucumber & 0.76 & $1^{\text {st }}$ & $1^{\text {st }}$ \\
Banana & 0.53 & $2^{\text {nd }}$ & $10^{\text {th }}$ \\
Watermelon & 0.53 & $3^{\text {rd }}$ & $10^{\text {th }}$ \\
Plantain & 0.50 & $4^{\text {th }}$ & $12^{\text {th }}$ \\
Citrus & 0.37 & $5^{\text {th }}$ & $16^{\text {th }}$ \\
\hline Vegetables & & & \\
\hline Okro & 0.72 & $1^{\text {st }}$ & $3^{\text {rd }}$ \\
Lettuce & 0.62 & $2^{\text {nd }}$ & $6^{\text {th }}$ \\
Garden egg & 0.58 & $3^{\text {rd }}$ & $7^{\text {th }}$ \\
Cabbage & 0.57 & $4^{\text {th }}$ & $8^{\text {th }}$ \\
Ugu & 0.55 & $5^{\text {th }}$ & $9^{\text {th }}$ \\
Amaranthus & 0.41 & $6^{\text {th }}$ & $15^{\text {th }}$ \\
Celosia & 0.28 & $7^{\text {th }}$ & $17^{\text {th }}$ \\
Corchorus & 0.14 & $8^{\text {th }}$ & $18^{\text {th }}$ \\
\hline Spices & & & \\
\hline Onion & 0.74 & $1^{\text {st }}$ & $2^{\text {nd }}$ \\
Pepper & 0.71 & $2^{\text {nd }}$ & $4^{\text {th }}$ \\
Ginger & 0.66 & $3^{\text {rd }}$ & $5^{\text {th }}$ \\
Turmeric & 0.49 & $4^{\text {th }}$ & $13^{\text {th }}$ \\
Garlic & 0.43 & $5^{\text {th }}$ & $14^{\text {th }}$ \\
\hline Sourc: Field survey 2020 & & &
\end{tabular}

Source: Field survey 2020.

\section{Satisfaction with Issues related to the Value Chain of Organic Fruits, Vegetables and Spices}

Table III shows that $55.8 \%$ of the farmers are very satisfied with business risks, organic land tenure system (53.3\%), technical skills and energy expended in management of the crops $(52.5 \%)$, finance availability $(50.8 \%)$ and off taking system (49.2\%). Main actors had high level (58.3\%) of satisfaction with issues related to the value chain of organic fruits, vegetables, and spices. This high level of satisfaction in the organic agriculture value chain related issues, implies that actors have tendency to participate more in the value chain of organic fruits, vegetables, and spices.

D. Benefits Derived by the Respondents from Participation in the Value Chain of Organic Fruits, Vegetables, and Spices

Table IV indicates that majority $(68.3 \%)$ of main actors had high level of benefits derived from participating in the value chain of organic fruits, vegetables, and spices. Among economic benefits, a higher percentage $(95.0 \%)$ benefited from zero expense on chemicals and inorganic pesticides and $94.2 \%$ benefited from greater net return and certainty of available market. Similarly, among environmental benefits main actors derived benefits from recycling of animal waste $(92.5 \%)$ and reduced exposure to drought and harmful chemical $(91.7 \%)$ meanwhile, from social benefits, they derived benefits from enhanced community development (88.3\%), enhanced social exposure and interaction $(85.0 \%)$ as well as social recognition $(82.5 \%)$. The fact that respondents derived such high benefits economically, environmentally, and socially could inform a high level of satisfaction. 
TABLE III: RESPONDENT'S SATISFACTION WITH RESPECT TO THE ISSUES THAT CONCERN THE VALUE CHAIN OF ORGANIC FRUITS, VEGETABLES AND SPICES

\begin{tabular}{|c|c|c|c|c|c|}
\hline Organic agriculture value chain issues & $\begin{array}{c}\text { Very } \\
\text { satisfactory }\end{array}$ & Satisfactory & Neutral & Unsatisfactory & $\begin{array}{c}\text { Very } \\
\text { unsatisfactory }\end{array}$ \\
\hline Organic inputs cost & 41.7 & 30.0 & 8.3 & 5.8 & 14.2 \\
\hline Quality control and certification system & 41.7 & 26.7 & 15.8 & 1.7 & 14.2 \\
\hline Pricing of organic fruits, vegetables, and spices & 43.3 & 35.8 & 18.3 & 2.5 & 0.0 \\
\hline Profit from sales of organic fruits, vegetables, and spices & 38.3 & 43.3 & 15.0 & 3.3 & 0.0 \\
\hline Time consumption in farm production & 46.7 & 28.3 & 22.5 & 2.5 & 0.0 \\
\hline $\begin{array}{l}\text { Technical skills and energy expended in management of the } \\
\text { crops }\end{array}$ & 52.5 & 23.3 & 18.3 & 5.8 & 0.0 \\
\hline Organic land tenure system & 53.3 & 27.5 & 15.0 & 4.2 & 0.0 \\
\hline Finance availability & 50.8 & 26.7 & 15.8 & 5.8 & 0.8 \\
\hline $\begin{array}{l}\text { Harvesting and postharvest handling such as packaging and } \\
\text { shelf-life storage }\end{array}$ & 36.7 & 44.2 & 15.8 & 3.3 & 0.0 \\
\hline Logistics such as transportation, marketing, and so on. & 19.2 & 45.8 & 30.0 & 5.6 & 0.0 \\
\hline Tedious nature of cultivating with hoe and cutlass & 32.5 & 44.2 & 18.3 & 3.3 & 1.7 \\
\hline Growth rate and future business plan & 46.7 & 35.8 & 11.7 & 5.0 & 0.8 \\
\hline $\begin{array}{l}\text { Business risks such as lower yield, pest infestation and } \\
\text { contamination, etc. }\end{array}$ & 55.8 & 25.8 & 11.7 & 5.0 & 1.7 \\
\hline Off taking & 49.2 & 28.3 & 17.5 & 4.2 & 0.8 \\
\hline Level of satisfaction & Frequency & \multicolumn{4}{|c|}{ Percentage } \\
\hline High satisfaction & 70 & \multicolumn{4}{|c|}{58.3} \\
\hline Low satisfaction & 50 & \multicolumn{4}{|c|}{41.7} \\
\hline Total & 120 & \multicolumn{4}{|c|}{100.0} \\
\hline
\end{tabular}

Source: Field survey 2020.

Table $\mathrm{V}$ shows that majority of the farmers have high knowledge $(55.5 \%)$ about issues related to organic agriculture practices and principles.

TABLE IV: BENEFITS DERIVED BY THE RESPONDENTS FROM PARTICIPATION IN THE VALUE Chain OF ORGanic Fruits, Vegetables

\begin{tabular}{lcc}
\multicolumn{3}{c}{ AND SPICES } \\
\hline Benefits & Not a benefit & A benefit \\
\hline Economic benefits & & \\
\hline Zero expense on chemicals and & 5.0 & 95.0 \\
inorganic pesticides & 5.8 & 94.2 \\
Greater net return & 5.8 & 94.2 \\
Certainty of available market & 13.3 & 86.7 \\
Produce price stability & 14.2 & 85.8 \\
Job security & & \\
\hline Environmental benefits & 7.5 & 92.5 \\
\hline Recycling of animal waste & 10.0 & 90.0 \\
Enhanced farm biodiversity & 15.0 & 85.0 \\
Improved soil quality & 13.3 & 86.7 \\
Reduced greenhouse gas emission & 12.5 & 87.5 \\
Cleaner groundwater and surface & & \\
water & 8.3 & 91.7 \\
Reduced exposure to drought and & & \\
harmful chemical & 17.5 & 82.5 \\
\hline Social benefits & 15.0 & 85.0 \\
\hline Social recognition & 11.7 & 88.3 \\
Enhanced social exposure and & 82 & 68.3 \\
interaction & 120 & 100.0 \\
Enhanced community development & &
\end{tabular}

TABLE V: LEVEL OF KNOWLEDGE OF THE RESPONDENTS ON ORGANIC AGRICULTURE PRACTICES AND PRINCIPLES

\begin{tabular}{|c|c|c|}
\hline Level of knowledge & Frequency & Percentage \\
\hline High knowledge & 66 & 55.5 \\
\hline Low Knowledge & 54 & 45.0 \\
\hline Total & 120 & 100.0 \\
\hline
\end{tabular}

Source: Field survey 2020.

\section{E. Main actors' Needs and Priorities based on Their Participation in the Value Chain of Organic Fruits, Vegetables and Spices}

Table VI shows that more fertile land among critical and immediate needs and priority of the respondents was ranked first with weighted score of 294.4. This is followed by increased market (283.3), broader value chain for organic fruits, vegetables, and spices (280.8), irrigation facilities (277.5) and research into affordable organic inputs (270). This implies that more fertile land, increased market, broader value chain for organic fruits, vegetables and spices, irrigation facilities as well as affordable organic inputs were main actors' critical and immediate needs and priorities as they participate in the value chain of organic fruits, vegetables, and spices.

F. Determinants of Main Actors' Satisfaction with Respect to the Issues related to the Value Chain of Organic Fruits, Vegetables and Spices

Table VII reveals that main actors' farm size $(\beta=0.21$; $p=0.02)$, knowledge $(\beta=0.19 ; p=0.04)$ and benefits derived $(\beta=0.30 ; p=0.00)$ determined their satisfaction with respect to the issues related to the value chain of organic fruits, vegetables, and spices. This implies that farm size contributed $21.0 \%$, knowledge $19.0 \%$ and benefits derived $30.0 \%$ to their high level of satisfaction. The implication is that knowledge, benefits derived, and farm size determined actors' satisfaction with respect to the issues related to the value chain of organic fruits, vegetables, and spices hence, they should be put into consideration in case of any intervention for organic fruits, vegetables, and spices.

TABLE VII: REGRESSION ANALYSIS OF DETERMINANT OF MAIN ACTORS' SATISFACTION WITH RESPECT TO THE ISSUES RELATED TO THE VALUE CHAIN OF ORGANIC FRUITS, VEGETABLES AND SPICES

\begin{tabular}{llll}
\hline Variable & $\beta$-value & t-value & p-value \\
\hline Main actors' age & -0.23 & -0.32 & 0.75 \\
Household size & -0.75 & -0.82 & 0.41 \\
$\begin{array}{l}\text { Farm size } \\
\text { Years of organic }\end{array}$ & 0.21 & -2.29 & $0.02 * *$ \\
$\begin{array}{l}\text { experience } \\
\text { Main actors' knowledge }\end{array}$ & 0.19 & -0.28 & 0.78 \\
$\begin{array}{l}\text { Benefits derived } \\
\text { Needs and Priority }\end{array}$ & 0.30 & 2.06 & $0.04 * *$ \\
& -0.02 & -3.14 & $0.00 * *$ \\
\hline
\end{tabular}

**Significant $\mathrm{p}<0.05$

Source: Field survey 2020. 
TABLE VI: NEEDS AND PRIORITIES OF THE RESPONDENTS BASED ON THEIR PARTICIPATION IN THE VALUE CHAIN OF ORGANIC FRUITS, VEGETABLES AND SPICES

\begin{tabular}{|c|c|c|c|c|}
\hline \multicolumn{5}{|c|}{ ORGANIC FRUITS, VEGETABLES AND SPICES } \\
\hline Need and priority items & $\begin{array}{c}\text { Critical and } \\
\text { immediate 50-100 }\end{array}$ & $\begin{array}{c}\text { Critical but not } \\
\text { immediate } 25-49\end{array}$ & $\begin{array}{l}\text { Not critical but } \\
\text { immediate } 1-24\end{array}$ & $\begin{array}{l}\text { Weighted } \\
\text { score }\end{array}$ \\
\hline More fertile land & 95.0 & 4.3 & 0.8 & 294.4 \\
\hline Increased market & 85.0 & 13.3 & 1.7 & 283.3 \\
\hline $\begin{array}{l}\text { Broader value chain for organic fruits, vegetables } \\
\text { and spices }\end{array}$ & 85.0 & 10.8 & 4.2 & 280.8 \\
\hline Irrigation facilities & 80.0 & 17.5 & 2.5 & 277.5 \\
\hline $\begin{array}{l}\text { Research into affordable organic inputs such as } \\
\text { organic fertilizers, pesticides, herbicides etc. }\end{array}$ & 72.5 & 25.0 & 2.5 & 270 \\
\hline $\begin{array}{l}\text { More public acceptability of organic fruits, } \\
\text { vegetables and spices }\end{array}$ & 73.3 & 23.3 & 3.3 & 269.8 \\
\hline Storage facilities & 69.2 & 28.3 & 2.5 & 266.7 \\
\hline Easier source of organic inputs & 70.0 & 25.0 & 5.0 & 265 \\
\hline $\begin{array}{l}\text { Research into packaged organic inputs such as } \\
\text { organic fertilizers, pesticides, etc. }\end{array}$ & 68.3 & 27.5 & 4.2 & 264.1 \\
\hline Processing facilities & 68.3 & 25.0 & 6.7 & 261.6 \\
\hline Loan & 62.5 & 32.5 & 5.0 & 257.5 \\
\hline Improved seeds & 61.6 & 34.2 & 4.2 & 257.4 \\
\hline
\end{tabular}

Source: Field survey 2020

G. Test of Difference in Main Actors' Satisfaction with Issues related to the Value Chain of Organic Fruits, Vegetables and Spices across the States in the NorthEastern Part of Nigeria

Table VIII shows that test of difference main actors' satisfaction with issues related to the value chain of organic fruits, vegetables and spices across the states was significant $(\mathrm{F}=4.35, \mathrm{p}=0.02)$. This means that while main actors differed in their satisfaction with respect to the issues related to the value chain of organic fruits, vegetables, and spices across the states.

TABLE VIII: TEST OF DIFFERENCE (ANALYSIS OF VARIANCE) OF MAIN ACTORS' SATISFACTION WITH RESPECT TO THE ISSUES RELATED TO THE VALUE CHAIN OF ORGANIC FRUITS, VEGETABLES AND SPICES

\begin{tabular}{ccccc}
\multicolumn{4}{c}{ VALUE CHAIN OF ORGANIC FRUITS, VEGETABLES AND SPICES } \\
Source of variation & $\begin{array}{c}\text { Mean } \\
\text { square }\end{array}$ & df & F-value & p-value \\
\hline Between groups & 465.10 & 3 & 4.35 & $0.02^{* * *}$ \\
Within groups & 107.01 & 117 & & \\
Total & & 120 & & \\
\hline
\end{tabular}

**Significant $\mathrm{p} \leq 0.05$.

Source: Field survey 2020.

Further analysis in Table IX reveals that the significant difference was between main actors' satisfaction from Gombe and Taraba with mean difference of $6.80(p=0.00)$, as well as between those actors from Taraba and Adamawa with mean difference of 2.95 ( $\mathrm{p}=0.00)$. The implication is that main actors differed greatly in their satisfaction with issues related to the value chain of organic fruits, vegetables and spices across states in the North-Eastern part of Nigeria. The difference could be because of several factors such as level of knowledge as well as benefits derived from organic fruits, vegetables and spices.

TABLE IX: Post Hoc (LSD) TEST OF DifFERENCE OF MAIN ACTORS SATISFACTION WITH RESPECT TO THE ISSUES RELATED TO THE VALUE Chain of ORganic Fruits, Vegetables and Spices ACROSS THE States IN THE NORTH-EASTERN PART OF NIGERIA

\begin{tabular}{cccc}
\hline $\begin{array}{c}\text { Main actors' } \\
\text { state }\end{array}$ & $\begin{array}{c}\text { Main actors' } \\
\text { state }\end{array}$ & Mean difference & p-value \\
\hline Adamawa & Gombe & 3.85 & 0.09 \\
Gombe & Taraba & 6.80 & $0.00^{* *}$ \\
Taraba & Adamawa & 2.95 & $0.00^{* *}$ \\
\hline **Significant $\mathrm{p}<0.05$ & & &
\end{tabular}

Significant $\mathrm{p} \leq 0.05$.

Source: Field survey 2020.

\section{CONCLUSION AND RECOMMENDATIONS}

Conclusively, majority of main actors are female, youth, married with average household size, they are smallholder farmers and are not organically certified due to lack of fund. Respondents dealt with cucumber, banana, watermelon, okro, lettuce, onion and pepper were among organic fruits, vegetables, and spices. They have high level of knowledge, benefit derived and satisfaction but their needs and priorities such as more fertile land, increased market and research into affordable organic inputs are critical and immediate. Main actors' farm size, level of knowledge and benefits derived determined their satisfaction with issues related to the value chain of organic fruits, vegetables, and spices.

It is therefore recommended that production and consumption of certified organic fruits, vegetables, and spices (especially cucumber, banana, watermelon, okro, lettuce, onion, and pepper) should be supported, promoted, and encouraged by international donors and organisations as well as governments. This can be done by increasing their tentacles of financial assistance to these actors as this will enable them to be able to register for organic certification. The fact that respondents were satisfied with issues related to the value chain of organic fruits, vegetables and spices is positive development and an indication that the production and consumption of organic fruits, vegetables and spices should be encouraged. However, there is need to be wary of actors' critical and immediate needs and priorities which could pose danger in the participation in the value chain. Frequent workshop and training about issues related to the value chain of organic fruits, vegetables and spices should be organised by all the developmental agencies for actors involved in the value chain. This is important to update respondents' knowledge about issues related to the value chain because this is one of the determinants of their satisfaction with issues related to the value chain of organic fruits, vegetables, and spices.

\section{ACKNOWLEDGMENT}

Yekinni, Oyedeji Taofeeq, Ladigbolu, Temitope Adejoju and Ogundijo, Olurotimi James appreciate the funding support for this project by the Swiss Agency for Development and Cooperation (SDC) through Bio-vision Africa Trust 
(BvAT) and Association of Organic Agriculture Practitioners in Nigeria (NOAN) for funding this research work.

\section{REFERENCES}

[1] O. J., Ogundijo and F., Dodo, Agricultural development in Nigeria: A review of approaches. African Journal for Sustainable Development, 5 (1), 23, 2015.

[2] M. S., Deshmukh and N. G., Tanaji, Organic farming for sustainable agricultural development. Kurukshetra - A Journal of Rural Development, 67(7), P. 6, 2019.

[3] R., Kaplinsky and M., Morris, A handbook for value chain research. Brighton: Institute of Development Studies, 2011, 1-109.

[4] H., Lu, J. H. Trienekens, S.W.F. Omta and S. Feng. The Value of Guanxi for Small Vegetable Farmers in China. British Food Journal, 110(4-5): 412-429, 2008.

[5] S., Setboonsarng, Organic agriculture, poverty reduction, and the millennium development goals, ADBI Discussion, 2006, Paper, No. 54, Asian Development Bank Institute (ADBI), Tokyo. http://hdl.handle.net/10419/53507.

[6] International Fund for Agricultural Development (IFAD) Organic agriculture and poverty reduction in Asia: China and India Focus. Rome: IFAD, 2005.

[7] United Nations Industrial Development Organization (UNIDO), Poverty reduction through productive activities Annual Report 2009, published on Sep 19, 2012 on https://issuu.com/unido/docs/annualreport2009/51.

[8] O. T., Yekinni and T. A., Ladigbolu, Training needs assessment of stakeholders on Ecological Organic Agricultural in Southwestern Nigeria. African Journal of Organic Agriculture and Ecology, 1, 2330, 2019.

[9] O. T., Yekinni, T. O., Bamidele and T. A., Ladigbolu, Gender dimension to involvement in Organic Agricultural in southwest Nigeria. African Journal of Organic Agriculture and Ecology, 1, 45$50,2019$.

[10] D. J., Connor, Organic agriculture and food security; A decade of unreason finally implodes. Field Crops Research, 225, 128-129, 2018.

[11] E., Meemken and M., Qaim, Organic agriculture, food security and the environment. Annual Review of Resource Economics, 2018.

[12] O. B., Oyesola and I. E., Obabire, Farmers' perception of organic farming in the selected local government areas of Ekiti state, Nigeria. Journal of Organic Systems, 6(1), 45-50, 2011.

[13] P. J., Aitchison, M. G., Bawden, D. M., Carroll, P. E., Glover, K., Klinkenberg, P. N., de Leeuw and P., Tuley, The Land Resources of North East Nigeria: The Environment, Volume 1, Land Resource Study Number 9, Land Resources Division, Tolworth Tower Surbiton, Surrey, England 1972 https://library.wur.nl/isric/fulltext/isricu_i00016124_001.pdf.

[14] O. T., Yekinni, T. A., Ladigbolu, R. T., Adeniyi, Benefits Derived from the Use of Information and Communication Technologies among Rural Farmers in Northeast Nigeria. Journal of Agricultural Extension, Vol. 23 (3); 117-125, 2019. https://dx.doi.org/10.4314/jae.v23i3.10

[15] African Union. The African Youth Charter, 2006. http://www.africaunion.org./root/ua/conferences/mai/hrst/charter\%20english.pdf.

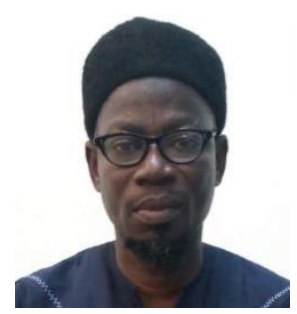

Oyedeji Taofeeq Yekinni, was born in Lagos, Nigeria on 21 June 1969. He had B.Sc. (in 1998), M.Sc. (in 2002) and Ph.D. (in 2011) degrees from the Department of Agricultural Extension and Rural Development, University of Ibadan, Nigeria.

He is currently an academic staff member at the University of Ibadan, Ibadan, Nigeria, from December 2010 till date. He had previously served in similar capacity at the Ladoke Akintola University of Technology, Ogbomoso, Nigeria, between 2005 till 2010.

$\mathrm{He}$ is a member of the Agricultural Extension Society of Nigeria (AESON), Rural Sociological Association of Nigeria (RuSAN), and International Society of Organic Agriculture Research (ISOFAR). He is a 2007 CODESRIA Laureate of Small Grant for thesis writing.

He has published articles in research areas such as Communication and ICT/new media, Agricultural enterprises, Sustainable environment and agricultural practices, Rural sociology, Agricultural programmes and policy, and Agricultural Extension Research methods. Some of the articles published are:
1. Yekinni O. T. (2010). Women's Participation in Development Programs and Food Security Status, Journal of Agricultural \& Food Information, Vol. 11 (1): 28-35.

2. Yekinni O. T. and L. A. Akinbile (2014). Comparison of use of Information and Communication Technologies between Agricultural Researchers and Extension Personnel in Nigeria. Journal of Agricultural Extension, Vol. 18(1): 13-22.

3. Olanrewaju, P. O., N. T. Meludu, O. T. Yekinni and O. O. AdeOluwa (2019). Assessment of traditional agricultural practices in Nigeria for possible conversion to organic agriculture production system. African Journal of Organic Agriculture and Ecology (AJOAE), Vol. 1: 31-38.

His area of research interest is agricultural extension communication for development. His focus has been to pursue issues of interest to the extension service clientele in Nigeria.

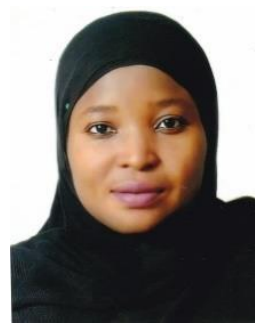

Ladigbolu Temitope Adejoju popularly called Tope is a Nigerian born in an ancient town (Oyo) from Oyo state on 7 th July 1980 . She received her tertiary education at the University of Ibadan, Ibadan, Nigeria, she holds a Doctorate degree in Agricultural Extension and Rural Development (2017) with bias for development communication. Spent her life conducting research that inform policy brief and influence people's life as well as their livelihood with the use of ICTs, videos and

drama.

She is working with an academic organisation in Nigeria as an Administrative Officer, she is married and currently lives in Ibadan, Oyo state, Nigeria. She volunteered as a producer and presenter on University of Ibadan campus radio while in school. Some of her publications among others include:

1. T. A., Ladigbolu and B. R., Olajide, Farmers' proclivity to use soap opera for sourcing agricultural information in Southwest Nigeria, Agricultura Tropica Et Subtropica, 51(4), 121-124, 2018. DOI: 10.1515/ats-2018-0013.

2. Yekinni, O. T., T. A., Ladigbolu and M. M., Atanda, Consumers' Motivating Factors to Purchasing Organic Foods in Oyo State, Nigeria. African Journal of Organic Agriculture and Ecology Volume 4, 45-54, 2020.

3. Olajide, B. R. and T. A., Ladigbolu, Farmers' information needs in soap opera utilisation for agricultural enterprise promotion in Southwestern Nigeria. Journal of Agricultural Extension Society of $\begin{array}{llll}\text { Nigeria, } & \text { Vol. } & 21(2) ; & \end{array}$ https://dx.doi.org/10.4314/jae.v21i2.12.

Dr Ladigbolu Temitope Adejoju, is an avid researcher with focus on developmental communication, sociology, organic agriculture, agricultural extension, and rural development. A member of Rural Sociological Association of Nigeria (RuSAN), Agricultural Extension Society of Nigeria (AESON) and International Society of Organic Agriculture Research (ISOFAR).

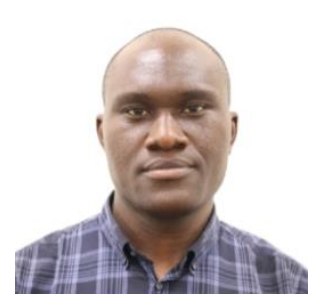

Ogundijo James Olurotimi currently resides in Yola, Adamawa state and was born in Ibadan, Oyo state, Nigeria on the $24^{\text {th }}$ September, 1982. Ogundijo James Olurotimi had his first leaving school certificate in Alafia Nursery and Primary Schools, Orogun, Ibadan in 1992 and his senior school certificate in 1998 at the Abadina College, University of Ibadan. Ogundijo James Olurotimi has a National Teachers Institute post-graduate diploma in education at the Usmanu Danfodiyo University, Sokoto in 2014 and a Bachelors degree in Agricultural Economics and Farm Management at the now Federal University of Agriculture, Abeokuta, Ogun state, Nigeria in 2008.

He is a seasoned agriculturist, community development expert, livelihood and entrepreneurial specialist and a researcher in the field of sustainability. He has more than 8 years working experience in areas of humanitarian intervention programs and project management at the American University of Nigeria, Yola, Adamawa State having served in different capacities as sustainability field research manager, food and agriculture intervention program manager, team lead for United Nations High Commissioner for Refugee (UNHCR) livelihood intervention project, lead trainer and facilitator for agricultural extension officers capacity building project in Adamawa state. He currently consults on livelihood and agricultural programs for Environmental Care Foundation (ECF) a Non-Governmental Organisation and serves as Production Manager for SembaAGro Nig Ltd both in Yola, Adamawa State. He has co-authored an article and a paper namely: 
1. Ogundijo O. J. and Egbeadumah, M. O. (2016). The prospect of exploring floodwater in strengthening irrigation farming in Northern Nigeria. Ibadan Sustainable Development Summit (2016) Book of Proceedings pp. 185 ISBN 978-978-98446-8-5.

2. Ogundijo, O. J. and Fardeen, D. (2015). Agricultural Development in Rural Nigeria: A review of approaches. African Journal for Sustainable Development (AJSD), Vol. 5(3) pp. 59-69 respectively.

His previous research interest focused on Biofuels, Aquaponics, Integrated Farming Practices, Sustainable Agriculture and Sustainable Livelihoods. He currently works on Organic agricultural practices and Organic Fertilizer Production.

Mr. Ogundijo is a certified Organic Agriculture Trainer and member of Organic Agriculture Practitioners of Nigeria (NOAN) and has offered consultancy services for different INGOs and NGOs over the years. Olurotimi is a passionate advocate for green environment and community transformative development. 